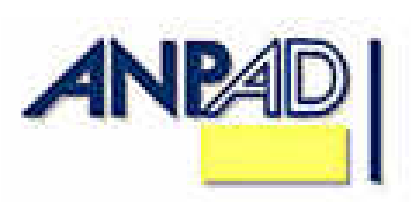

Available online at

http://www.anpad.org.br/bar

BAR, Curitiba, v. 5, n. 4, art. 2, p. 275-288,

Oct./Dec. 2008

\title{
Drivers of Discretionary Firm Donations in Brazil
}

\author{
Rodrigo Bandeira-de-Mello * \\ E-mail address: rmello@univali.br \\ Programa de Pós-Graduação em Administração e Turismo - Universidade do Vale do Itajaí \\ Biguaçu, SC, Brazil.
}

\section{Rosilene Marcon}

E-mail address: rmarcon@ univali.br

Programa de Pós-Graduação em Administração e Turismo - Universidade do Vale do Itajaí

Biguaçu, SC, Brazil.

\section{Anete Alberton}

E-mail address: anete@ univali.br

Programa de Pós-Graduação em Administração e Turismo - Universidade do Vale do Itajaí

Biguaçu, SC, Brazil.

\section{ABSTRACT}

Discretionary firm donation is usually related to the stakeholder theory and corporate social performance. Although theoretical explanations for this social behavior are pervasive in related literature, empirical modeling remains underdeveloped. We developed an explanatory structural model of discretionary firm donation using firm and industry level indicators. Unlike previous research, we estimated the explanatory power of the construct we called stakeholder orientation. Our tentative model was tested on a Brazilian sample of 101 publicly traded donor firms, using data on firm donations to social projects and to political candidates in electoral campaigns. The main results suggest that discretionary donation seems to be a strategy for managing conflicting claims in highly stakeholder oriented firms; the characteristics of the firm are more important than industry effects in explaining firm donations; and large firms, showing slack resources, and with a less concentrated ownership structure tend to engage in discretionary donation more intensively.

Key words: stakeholder theory; discretionary firm donation; emerging markets.

Received 19 October 2007; received in revised form 01 September 2008.

Copyright (C) 2008 Brazilian Administration Review. All rights reserved, including rights for translation. Parts of this work may be quoted without prior knowledge on the condition that the source is identified.

\footnotetext{
* Corresponding author: Rodrigo Bandeira-de-Mello

Universidade do Vale do Itajaí - UNIVALI, Rua Patrício Antonio Teixeira, 317, Jardim Carandaí, Biguaçu, SC, 88160-000, Brazil.
} 


\section{INTRODUCTION}

Discretionary firm donation is usually associated to the stakeholder theory (Adams \& Hardwick, 1998; Waddock \& Graves, 1997), corporate social performance (McGuire, Sundgren, \& Schneeweis, 1988; Ullmann, 1985) and corporate political strategies (Lenway \& Rehbein, 1991; Roberts, 1992). Different theoretical explanations of why and how intensely a firm should engage in such social behavior is pervasive in related literature; however, they do not converge (Freeman, 1999). One can rely on the reasoning of maximizing conventional financial performance, as advocated by the instrumental stakeholder theory, or on the social imperative of maximizing all stakeholders' gains, as the ultimate objective of the firm, an assumption of the normative stakeholder theory (Donaldson \& Preston, 1995).

Despite theoretical pervasiveness, empirical research on corporate donation activities is still underdeveloped. As Harrison and Freeman (1999) point out, business and society is relatively young as a discipline and, therefore, its empirical tools are only beginning to be developed. Some exceptions are the work of Adams and Hardwick (1998), who attempted to model company-specific factors associated to levels of discretionary firm donations, the study of social responsibility disclosure by Roberts (1992), who used firms' contributions to political parties and cash given to charity as independent variables, and the longitudinal analysis of Campbell, Moore and Metzger (2002). "Linkages between the level of donations and company-specific characteristics, such as leverage and firm size, could help stakeholders such as shareholders, creditors and customers to make better informed business decisions" (Adams \& Hardwick, 1998, p. 642).

In Brazil, research into stakeholder theory and corporate social responsibility is essentially descriptive (Almeida, Fontes, \& Martins, 2000; Alves, 2001; Ashley, Coutinho, \& Tomei, 2000; Coelho, 2004; Coutinho \& Macedo-Soares, 2002; Serpa \& Fourneau, 2007), developed under the case study research design (Andrade, 2000; Kreitlon \& Quintella, 2001; Machado \& Lage, 2002; Xavier \& Souza, 2004), or with a focus on managerial perception (Garay, 2006; Macke \& Carrion, 2006; Serpa, 2006). Some studies associate corporate social responsibility with firm performance using large datasets (Alberton, 2003; Campos, 2003; Souza \& Marcon, 2003), but none of these addresses the issue of firm donation behavior.

We intend to fill this gap by testing an explanatory model of discretionary firm donations by Brazilian firms. We argue that explanations for the firm donation phenomenon should take into account the complexity of both industry and organizational settings. Previous research used regression models with a parsimonious selection of key variables with low shared variance and high unique contribution (Adams \& Hardwick, 1998). Differently, our model develops and tests what we call the stakeholder orientation concept, a firm-level construct that takes into account relevant organizational characteristics all together. We seek to understand not the isolated effects of independent variables, but the profile of firms more prone to engage in high levels of corporate donations.

\section{DRIVERS OF DISCRETIONARY FIRM DONATION}

We draw from the stakeholder theory (Cornell \& Shapiro, 1987; Hill \& Jones, 1992; Roberts, 1992; Ullmann, 1985) and related research on corporate social responsibility and corporate social performance (Donaldson \& Preston, 1995; Harrison \& Freeman, 1999; Hillman \& Keim, 2001) to explain firm donations. Following Adams and Hardwick (1998), we consider "that stakeholder theory has intuitive appeal in providing insights into why companies might make discretionary payments to support charitable and other social activities" (p. 644). Before we present the research hypotheses, two questions within the realms of the stakeholder theory need to be addressed: to whom and why make donations. 
We focus on discretionary donations to primary stakeholders (Clarkson, 1995), specifically, for two broad, aggregated groups, namely government and community. These two groups have notorious salience to firm management in Brazil. The characteristics of a weak, erratic and hostile government (Pearce, 2001) exerts a negative influence on business firms, forcing them to seek protection or some form of association in order to survive and to profit. As suggested by Smith (1994), in emerging countries, such as Brazil, Taiwan and Hungary, uncluttered by social initiatives, even small, wellconceived grant programs might have a large impact on the success of a firm. The relevance of the government stakeholder is evident when the implementation of stakeholder principles depends upon government intervention and regulation (Buchholz \& Rosenthal, 2004; Freeman, 1998; Keim \& Baysinger, 1988). According to Freeman and Reed (1983), even in developed countries, the government, as well as its regulatory agencies, has had increasingly more power. The community stakeholder is also important to a firm's strategic management (Altman, 1998; Berman, Wicks, Kotha, \& Jones, 1999; Waddock \& Graves, 1997). In Brazil, Schommer (2000) and Coelho (2004) used donation to social projects as a proxy for the relationship between the firm and the community.

Stakeholder theory provides conceptual grounds to explain why firms engage in donation activities. According to Donaldson and Preston (1995), stakeholder theory may view the firm as a nexus of explicit and implicit contracts among multiple stakeholders, similar to transaction cost economy (Williamson \& Winter, 1991) or to agency theory (Jensen \& Mechling, 1976). If managers are to coordinate such contracts in ways that the firm will benefit from superior conventional performance in the long run, then one may infer an instrumental reasoning for engaging in firm donations (Jones, 1995). On the order hand, according to the notion implied by the normative stakeholder theory, this coordination effort would only succeed if the underlying instrumental notion of opportunistic behavior could be shifted to a more substantive view of stakeholder relationship, based on shared values of fairness (Donaldson \& Preston, 1995).

We follow the instrumental reasoning to draw hypothesis on drivers of corporate donation to salient stakeholders. We conceptualize the level of discretionary donations as being driven by both firm- and industry-specific factors. As for the firm-level antecedent, we define the stakeholder orientation construct. It reflects the extent to which the firm is oriented towards stakeholder responsiveness. Companies with higher stakeholder orientation tend to use corporate donations strategically to take into account stakeholder claims and to profit from superior performance. We propose the following:

\section{$\mathrm{H}_{1}$ : Stakeholder orientation drives firm donation intensity.}

We define stakeholder orientation as a firm-level construct. Previous empirical models took into account unique contributions of a set of firm characteristics to explain firm donation (Adams \& Hardwick, 1998). In our model, instead of grasping unique variances of each variable, we propose a set of firm-level indicators to measure and to define stakeholder orientation. We believe that the stakeholder orientation construct explain firm donation better than a model with unique individual firm characteristics. By composing firm profiles we are better able to take into account the complex and interactive features of these organizational phenomena. We suggest that the following companyspecific characteristics indicate the stakeholder orientation profile of a firm: slack resources, size, capital structure and ownership structure.

Profitability ratios may indicate the presence, or absence, of slack resources. We assume that profitable firms are more prone to engage in stakeholder related activities. However, there is no consensus about the causal link between financial and social performance (Waddock \& Graves, 1997). As proposed by Ruf, Muralidhar, Brown, Janney and Paul (2001), investment in social projects leads to better financial performance. On the other hand, the greater the financial performance, the greater the level of slack resources to be invested in social projects (Adams \& Hardwick, 1998; Cochran \& Wood, 1984; McGuire et al., 1988; Preston \& O’Bannon, 1997; Roberts, 1992; Ullmann, 1985). To account for this circularity, we measured slack resources by the firm's past profitability. We then propose the following:

\section{$\mathrm{H}_{2}$ : The higher the past profitability of a firm, the higher its stakeholder orientation.}


The other three company-specific characteristics that indicate the level of stakeholder orientation of a firm are related to structural factors. First of all, firm size is expected to contribute to knowledge concerning its stakeholder orientation profile. Large firms are more visible to the public, receive more pressures from organized groups and are expected to make more donations both to the communities where they are geographically located, and to the government (Adams \& Hardwick, 1998; Cowen, Ferreri, \& Parker, 1987; Roberts, 1992).

\section{$\mathbf{H}_{3}$ : The larger the firm size, the higher its stakeholder orientation.}

Secondly, stakeholder oriented firms tend to make specific decisions concerning their capital structure. The level of the firm's debt is usually considered as a proxy for risk measure (Adams \& Hardwick, 1998; Cornell \& Shapiro, 1987; McGuire et al., 1988; Roberts, 1992). A firm willing to continue to satisfy its stakeholders' implicit claims is expected to avoid incurring financial risks and will adopt a low leverage position. Therefore, we posit the following:

\section{$\mathrm{H}_{4}$ : Firms with a strong stakeholder orientation tend to show low levels of firm leverage.}

Finally, ownership concentration may be an indication of stakeholder orientation. Firm ownership and governance structures vary across countries due to factors such as the political regime, the legal system, the capital market structure and the stability of profit rates (Demsetz \& Lehn, 1985; Siffert, 1998; Thomsem \& Pedersen, 1997). In Brazil, besides market regulation, firm size and capital structure determine the level of ownership concentration of firms (Siqueira, 1998). Larger firms tend to diversify their ownership structure in order to lower risks and to reduce the cost of capital (Demsetz \& Lehn, 1985). The market is willing to pay a premium on stocks of firms with a less concentrated ownership structure (Vieira \& Mendes, 2004). As stated above, large firms are more willing to be oriented towards stakeholders as they are more visible and suffer more pressure from stakeholder groups. Therefore, it is reasonable to expect that stakeholder oriented firms show less concentrated ownership structures. The positive evaluation of firm governance practices by the market provide an incentive for stakeholder oriented firms to diversify their ownership structure. We then posit the following:

\section{$H_{5}$ : Firms with a strong stakeholder orientation tend to show less concentrated ownership} structures.

Literature has also mentioned industry-related antecedents of firm donations. The industry in which the company operates influences its donation behavior. Industry structure differences are an important economic determinant of firm performance, exert influence on the firm's strategic actions (McGahan \& Porter, 1997; Porter, 1980) and may entail differences in the way incumbents relate to their stakeholders, specifically due to differences in industry concentration (Lenway \& Rehbein, 1991). Firms that deal with a more regulated environment tend to engage in closer relationships with the government than their counterparts in less regulated environments. Samuels (2003), analyzing data on Brazilian donations to election campaigns, found an association between political donation and industry. By the same token, firms whose activities pose a greater risk to the community tend to develop countermeasures to compensate for possible damage or to form a positive image for the firm (Boeira, 2002). Industry effects seem to play a role in firm donations.

\section{$\mathrm{H}_{6}$ : Industry effects drive firm donation intensity.}

\section{RESEARCH DESIGN}

We tested firm and industry-level antecedents of firm donation using Structural Equation Modeling [SEM]. According to our hypotheses, firm size and past profitability are causal, or formative, indicators of stakeholder orientation, while firm leverage and ownership structure are effect, or reflective, indicators. Therefore, stakeholder orientation is empirically defined as a Multiple Indicator 
Multiple Causes [MIMIC] factor (Kline, 2005). Depicted in Figure 1, stakeholder orientation is a latent variable represented in an oval. Observed variables are represented in rectangles. To identify the model, we constrained the ownership concentration loading to -1, making it the reference item to scale the stakeholder orientation construct. The negative sign reflects the inverse relation between ownership concentration and stakeholder orientation. We allowed the cause indicators to covary. Measurement errors for the effect indicators of the Stakeholder Orientation factor also were allowed to covary, indicating possible common causes of non-explained variation. Figure 1 shows only estimable parameters. Every arrow without an explicit parameter indicates a free model parameter. A total of 14 estimable parameters were free to vary.

Figure 1: Structural Model of Discretionary Firm Donation

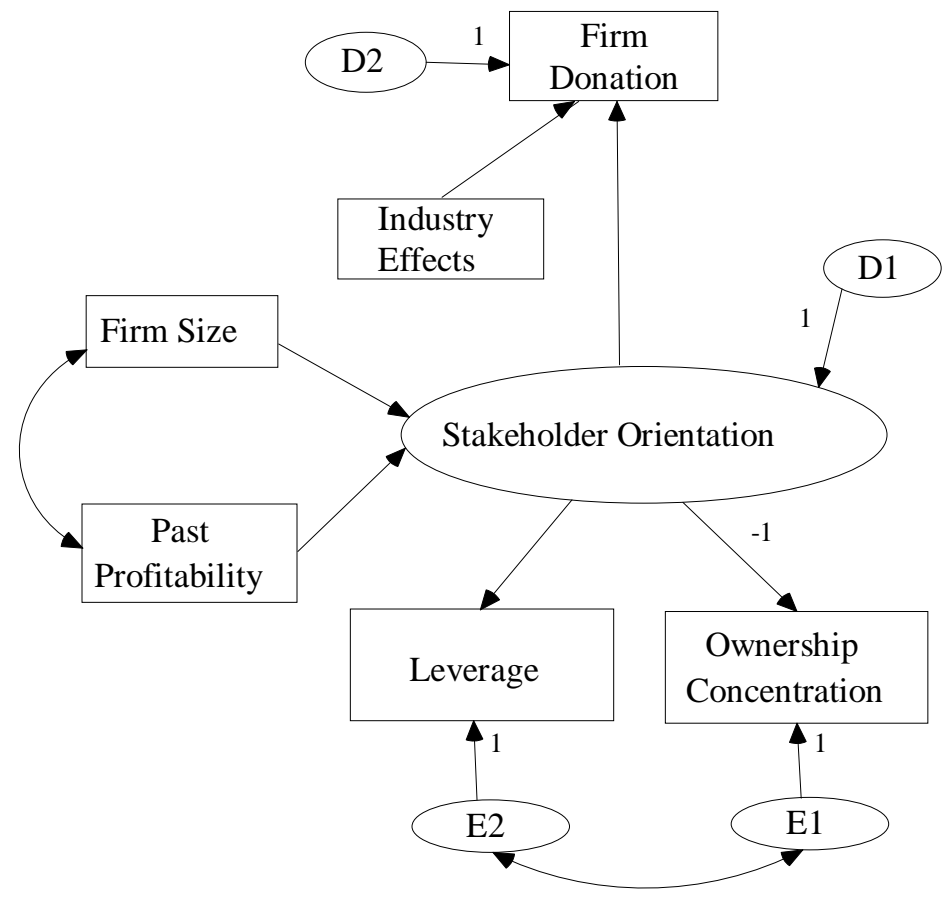

Only data from publicly traded firms were considered due to their reliability. Data were gathered from three sources: (1) the ECONOMATICA database (n.d.); (2) the Guia EXAME de boa cidadania corporativa (Revista Exame, 2000, 2001, 2002); and (3) official data on firm donation in electoral campaigns. The ECONOMATICA database provides the accounting and financial data of listed firms on the main stock exchanges and were used to gather data on firm and industry-level variables.

The Guia EXAME reports social investments and cash giving on several categories. We used it to gather data on firm donations to the community stakeholder by adding up yearly firm donations to projects involving: senior citizens, children and teenagers, the handicapped, community, culture, health and education, environment and social volunteers. Official reports on firm donations for political candidates, in the major electoral campaign of 1998 for President, senators, governors and representatives, provided donation data for the government stakeholder. Although there are criticisms about the reliability of these measurements, Samuels (2003) points out that Brazilian official data do not consist of random numbers, and exploring them reveals patterns of donations between firms, sectors and candidates. Roberts (1992) used corporate political action committee contributions, Balabanis, Philips and Lyall (1998) used donations to a political party, and Adams and Hardwick (1998) used discretionary donations to political causes.

We limited our analysis to a four-year time frame, from 1999 to 2002. Data on yearly donations to the community stakeholder were collected from 2000 to 2002 (there were no comparable data in 
1999). In our proposed model, firm donations are measured by a composition of political (government) and social (community) firm donations. All other indicators were average yearly figures. Table 1 shows operational definitions for each measured variable.

Table 1: Operational Definitions of Observed Variables

\begin{tabular}{|c|c|}
\hline Indicators & Operational Definition \\
\hline Firm Donation & $\begin{array}{l}\text { This is the sum of political donations and social donations for each firm. Firms' political } \\
\text { donations are the amounts donated from each firm to political candidates in the } 1998 \\
\text { election for President, governors, senators and representatives (US Dollars). Firms' } \\
\text { social donations are the sum of the amounts donated by each firm in social projects } \\
\text { divided by three (years of } 2000,2001 \text { and 2002). Figures are in US Dollars, considering } \\
\text { the exchange rate on the last business day of each year. The natural logarithm } \\
\text { transformation was used to achieve a univariate normal distribution. }\end{array}$ \\
\hline Past P & Yearly average of firms' profitability (Return on Assets) for 1997 and 1998. \\
\hline Leve & $\begin{array}{l}\text { This is the yearly average debt-to-asset ratio, considering the four-year time frame } \\
\text { (1999-2002). The natural logarithm transformation was used to achieve a univariate } \\
\text { normal distribution. }\end{array}$ \\
\hline Firm Size & $\begin{array}{l}\text { This is the average of firms' total assets in thousands of U.S. dollars considering the } \\
\text { four-year time frame (1999-2002). The natural logarithm transformation was used to } \\
\text { achieve a univariate normal distribution. }\end{array}$ \\
\hline $\begin{array}{c}\text { Ownership } \\
\text { Concentration }\end{array}$ & $\begin{array}{l}\text { Average percentage of the total number of shares that is in possession of the main } \\
\text { shareholder, for } 1999 \text { to } 2002 \text {. Since we considered the percentage related only to the } \\
\text { total of voting stocks, this variable can reach the value of } 1 \text {. }\end{array}$ \\
\hline Industry Effects & $\begin{array}{l}\text { To capture industry differences on firm donations, we used a measure of industry } \\
\text { donation intensity. It is the ratio of the industry aggregate amount of firm donation to the } \\
\text { industry's average firm size. }\end{array}$ \\
\hline
\end{tabular}

The research sample consisted only of donating firms listed in 1998 the ECONOMATICA database (n.d.). Since we did not sample non-donor firms, our population and generalization attempts refer only to the population of donor firms. Our dependent variable measured the donation intensity. Therefore, our model explained the drivers of donation intensity after the company has decided to engage in this social behavior.

Comments on how we handled data on firm donations are required. First, our decision to sum up two different variables - social donations, based on an annual average of three years, and political donations in a single year - would attribute more importance to political donations than to social donations. However, while social donations reflect a 3-year average, political donation reflect an election average (four-year period), which would justify our decision. Second, the composition of firm donations from political and social donations can be justified by the fact that it is very difficult to isolate their unique effects, since donations to the community could have been made to please the stakeholder government, and political donations could have been motivated by the firm's intention to indirectly assist a specific community (Adams \& Hardwick, 1998).

We decided to exclude financial institutions, due to their high leverage ratios, and firms whose industry was labeled others in the ECONOMATICA database. To improve sample quality, we conducted a microscopic screening, investigating possible causes for atypical data, e.g. extreme values of profitability like $500 \%$, in order to decide in favor of their exclusion. To compute yearly averages for observed variables, we considered firms having at least two years of data; otherwise we assigned a missing data. Hence missing values were generated by firms which had informed atypical, miscalculated values, or for firms that did not have at least two years of data (either because it was not informed or because the firm went bankrupt, merged or was acquired). The chi-square statistic to test for MCAR pattern (missing completely at random) was .517 ( $\mathrm{p}<.676)$. We then estimated missing values using the EM algorithm for data imputation provided by the SPSS 13. 
The final sample consisted of 101 donating firms in 15 industries. Hair, Anderson, Tatham and Black (1998) point out that at least 5 respondents to parameter are allowed, with 10 being more acceptable, and a minimum sample size of 50 for ML estimation, but 100-200 being more appropriate. Other suggestions are a minimum of 100 cases (Kline, 2005), 15 cases per measured indicator (Stevens, 2001), 5 cases per parameter (Bentler \& Chou, 1987), all of them considering normality assumptions. Our original sample generated, for the final model, 9 cases per parameter and 16.8 cases per indicator, very close to minimum requirements. Only the variable past profitability rejected the normality hypothesis, for the Kolmogorov-Smirnov test, at 5\%. After variable transformation, outliers were not a problem to fit the model.

We directly estimated the model in Figure 1 using ML estimation performed by AMOS 6.0. The Bootstrapt method was used to test for robustness. We also compared our model with a direct effects model, in which all observed variables pointed directly to the dependent variable, allowing for covariances among predictors.

\section{RESULTS}

Donating figures ranged from US\$2,752.29 to US\$ 4,900,469.71 (Vale, Mining), with an average of US\$ 575,451.89. All other variables showed large variations. Table 2 shows the means, standard deviations and minimum and maximum figures for each variable, using original, not transformed values.

Table 2: Descriptive Statistics for Observable Variables

\begin{tabular}{|c|c|c|c|c|}
\hline Original Variables & Min. & Max. & Mean & Std.Dev. \\
\hline Firm donation (US\$) & $2,752.29$ & $4,900,469.71$ & $575,451.89$ & $994,651.13$ \\
\hline Industry Effects & 0.0007 & 0.62 & 0.25 & 0.16 \\
\hline Ownership Concentration (\%) & 8.55 & 100 & 61.92 & 21.20 \\
\hline Past Profitability (\%) & -112.55 & 22.40 & 0.13 & 14.88 \\
\hline Leverage & 0.16 & 1.68 & 0.57 & 1.46 \\
\hline Size (1.000 US\$) & $13,226.79$ & $31,327,284.97$ & $1,772,951.90$ & $3,673,935.80$ \\
\hline
\end{tabular}

Table 3 shows the correlation matrix for all observed variables. Except for Leverage, all variables show significant correlations with Firm Donations. Other significant correlations indicate that large firms appear to have less ownership concentration levels (-.248), and slack resources, or past profitability (.258). Firms which had experienced good profits tend to be less leveraged in the subsequent period (-.403).

Table 3: Pearson Correlation Matrix for Observable Variables

\begin{tabular}{l|c|c|c|c|c}
\hline VARIABLES & 1 & 2 & 3 & 4 & 5 \\
\hline 1. Firm Donation & 1 & & & & \\
2. Industry Effects & $0.173^{*}$ & 1 & & & \\
3. Ownership Concentration & $-.251^{* *}$ & -.088 & 1 & & \\
4. Past Profitability & $.357^{* * *}$ & -.141 & -.096 & 1 & \\
5. Leverage & -.062 & $.188^{*}$ & $-.168^{*}$ & $-.403^{* * *}$ & 1 \\
6. Firm Size & $.532^{* * *}$ & -.084 & $-.248^{* *}$ & $.258^{* * *}$ & .015 \\
\hline$* * * \mathrm{p}<.01 * * \mathrm{p}<.05 * \mathrm{p}<.10$ & & & &
\end{tabular}

The initial estimation of the model in Figure 1 shows poor fit and offending estimates. We decided to eliminate the leverage indicator for empirical reasons (modification indexes and correlation residuals), although it was not theoretically impossible. Indeed, we were attempting to find the best 
indicators for the concept, and this new specification sounded reasonable. However, hypothesis $\mathrm{H} 4 \mathrm{did}$ not hold.

For the revised model, stakeholder orientation had only ownership concentration as its effect indicator. The new model was overidentified with 4 degrees of freedom. ML estimation showed no offending estimates. Table 4 presents estimated parameters and some measures of fit.

Table 4: Model Parameter Estimates for the Revised Model

\begin{tabular}{|c|c|c|c|c|}
\hline Model Parameters & Unstandardized & Std. Error & p-value & Standardized \\
\hline \multicolumn{5}{|l|}{ Regression Weights } \\
\hline Stakeholder Orientation $\rightarrow$ Firm Donation & 1.726 & .712 & .015 & .752 \\
\hline Industry Effects $\rightarrow$ Firm Donation & .253 & 083 & .002 & .236 \\
\hline Firm Size $\rightarrow$ Stakeholder Orientation & .369 & .158 & .019 & .643 \\
\hline Past Profitability $\rightarrow$ Stakeholder Orientation & 170 & .081 & .035 & .334 \\
\hline Stakeholder Orientation $\rightarrow$ Ownership Concentration & -1.000 & & & -.301 \\
\hline \multicolumn{5}{|l|}{ Covariances } \\
\hline Past Profitability $\leftrightarrow$ Firm Size & .503 & .201 & .013 & .258 \\
\hline \multicolumn{5}{|l|}{ Disturbances and Measurement error variances } \\
\hline Stakeholder Orientation & .208 & 208 & .318 & \\
\hline Firm Donation & 1.142 & 636 & .073 & \\
\hline Ownership Concentration & 5.718 & .835 & .000 & \\
\hline \multicolumn{5}{|l|}{ Squared Multiple Correlations (R2) } \\
\hline Donation & .621 & & & \\
\hline Stakeholder Orientation & .636 & & & \\
\hline \multicolumn{5}{|l|}{ Chi-Square $4.237(\mathrm{p}<.375)$} \\
\hline \multicolumn{5}{|l|}{ Joreskog GFI .983 } \\
\hline \multicolumn{5}{|l|}{ Joreskog AGFI .937} \\
\hline \multicolumn{5}{|l|}{ Steiger-Lind RMSEA .024 (.000-.155) } \\
\hline \multicolumn{5}{|l|}{ NFI .938 } \\
\hline AIC 26.237 & & & & \\
\hline Bollen-Stine bootstrap test $p<.222$ & & & & \\
\hline
\end{tabular}

Our revised model reached acceptable fit. All indexes were fairly acceptable. Only the RMSEA index showed mixed results. While the lower bound of its $90 \%$ confidence level was zero, indicating a good fit of the model with the population, its upper bound was greater than the traditional cut-off value of .10. However, this is likely to happen in smaller samples (Kline, 2005). The Bentler-Bonett normed fit (NFI) showed values greater than .90, indicating significant improvements from the baseline model of no correlations (the null model). We also tested for robustness using bootstrap methods. The Bollen-Stine bootstrap test did not reject the null hypothesis that the model is correct $(\mathrm{p}<.222)$. To verify whether our model was better than the direct effects model, we tested for competing models. The Akaike Information Criterion [AIC] for a direct-effects only model (.42) was greater than our revised model (26.23). As Kline (2005) argues, for testing competing models, the lowest AIC index indicates the best model solution.

Looking at the squared multiple correlations in Table 4, 64\% of the stakeholder orientation factor variance was explained by its indicators, indicating a good measurement for this construct. All indicators of this construct were significant ( $\mathrm{p}<.05)$. Therefore, these results support hypotheses $\mathrm{H}_{2}$, $\mathrm{H}_{3}$, and $\mathrm{H}_{5}$., i.e., firm size (.643), past profitability (.334), and ownership concentration (-.301) are good indicators of the firm's Stakeholder Orientation level.

The model explained $62 \%$ of firm donation variation. All estimated regression weights in Table 4 were significant $(\mathrm{p}<.05)$ and showed the expected signs. Stakeholder orientation showed a positive impact on firm donation (.752). This supported hypothesis $\mathrm{H}_{1}$. Industry effects were also found to be 
significant, even though their effects on firm performance were less important than the Stakeholder Orientation influence (.236). This supported hypothesis $\mathrm{H}_{2}$.

Finally, we re-estimated the revised model controlling for government ownership control, since state-controlled firms would be more generous in making donations as a way of implementing public policy or a government bargaining strategy with key political actors. This model did not have a good fit. In fact, data did not show any statistical differences between the donation averages of statecontrolled firms and the others $(\mathrm{p}<.630)$.

\section{DISCUSSION AND LIMITATIONS}

We examined drivers of discretionary firm donation for Brazilian companies. We estimated a structural model of firm donation using two exogenous variables: a firm-level construct, stakeholder orientation and industry effects. Five of our six initial hypotheses hold for these data. Stakeholder orientation and industry effects were found to be significant drivers of levels of firm donation $\left(\mathrm{H}_{1}\right.$ and $\left.\mathrm{H}_{2}\right)$. The concept of Stakeholder Orientation, being measured by firm size $\left(\mathrm{H}_{2}\right)$, past profitability $\left(\mathrm{H}_{3}\right)$, and ownership concentration $\left(\mathrm{H}_{5}\right)$ was found to be a better predictor of firm donation intensity than if all these indicators were taken separately. The model predicted $62 \%$ of the firm donation variance.

Firm size and slack resources (past profitability) played a major positive role in forming the profile of a stakeholder oriented firm. These results converge with previous literature (Adams \& Hardwick, 1998; Cowen et al., 1987; McGuire et al., 1988; Roberts, 1992). Lenway and Rehbein (1991) suggest that large firms are more prone to engage in political activity because of (a) their access to resources pay the fixed costs of political activity; (b) top managers transfer their prestige to political activity; and c) their abundant expertise. As our measurement model suggests, large firms are subject to more stakeholder pressures and tend to show a less concentrated ownership structure. This is consistent with Ullmann (1985), who posits that firms with less decentralized structures are prone to deal with a large number of different stakeholders.

We did not find support for the influence of stakeholder orientation on firm leverage, even though capital structure is usually a relevant indicator of a firm's social behavior, as we stated in hypothesis $\mathrm{H}_{4}$. Our findings on capital structure differ from studies that were conducted abroad (Adams \& Hardwick, 1998; Cornell \& Shapiro, 1987; McGuire et al., 1988; Roberts, 1992), indicating possible contextual differences in stakeholder management practices.

Industry characteristics do play a role in explaining donation variation, as we previously expected. Conversely, Adams and Hardwick (1998) did not find a significant industry effect in their British data. Possible explications are differences in the number of analyzed industries (four broad aggregates in the foreign study versus 15 Brazilian industries) and differences in the nature of the institutional setting (Luk, Yau, Chow, Tse, \& Sin, 2005; Pearce, 2001).

Stakeholder orientation was found to be positively associated with firm donations. This implies stakeholder management practices through corporate donations. Stakeholder orientation was more important than industry differences in explaining firm donation. One may infer that it is not because firm $\mathrm{A}$ is operating within industry $\mathrm{A}$, in which donation is more intense, that it will donate more than firm B in industry B, less intensive. In fact, what appears to motivate firms to donate more or less is their level of stakeholder orientation.

Finally, unlike previous research (Adams \& Hardwick, 1998), the stakeholder orientation concept was found to be a better predictor of firm donation intensity than the unique effects of its indicators. Future research should focus on developing new indicators, besides past profitability, firm size and ownership concentration. The encompassing concept of organizational orientation may better take into account the complexity of the stakeholder management practices. 
Limitations may call for caution when analyzing the results. First, although we reached some minimum requirements of sample size, our small sample may have generated inconsistent parameters and decreased power in significance tests. However, the model was not rejected in Bootstrapt estimation. Second, despite the fact that data on firm donations to the community were gathered from secondary sources and consisted of aggregated values of firm cash giving in projects related to several categories, these areas, although significant, may not represent the totality of a firm's social activities (Coelho, 2004; Vergara \& Branco, 2001). Indeed, we focused only on two stakeholder groups, the community and the government, which are intrinsically interrelated (Adams \& Hardwick, 1998). Finding measures capable of capturing every aspect of stakeholder management remains is a challenge to the stakeholder theory (Donaldson \& Preston, 1995; Harrison \& Freeman, 1999; Hillman \& Keim, 2001).

Regarding data quality, several firm projects listed in the Guia EXAME contained a ND entry, i.e. not declared, and were assigned the value of zero. This could downwardly bias the value of the dependent variable. This problem was attenuated by the fact that these entries were collapsed into yearly figures. Furthermore, we relied only on one source to gather data on social donations and only on publicly traded firms, which left out other possible social activities of sampled firms as well as several firms that were listed in the Guia EXAME that were not publicly traded companies. For these reasons, one would expect large measurement errors for firm donations. Since we did not expect our data on firm donations to be fully reliable, we could set firm donation construct reliability at 0.7 , the least commonly expected. However, this estimation showed offending estimates and did not improve goodness-of-fit indices. Nevertheless, our final model predicted firm donation reasonably well.

\section{CONCLUSIONS}

We can outline three conclusions from these results: (a) discretionary donation seems to be a strategy for managing stakeholder claims; (b) firms' characteristics are more important than industry effects in explaining firm donations; and (c) large firms with slack resources and a less concentrated ownership structure tend to show strong stakeholder orientation. Managers in stakeholder oriented firms seem to cope with conflicting stakeholder claims by using cash giving practices.

Future research should continue to enhance construct validity for both industry effects and stakeholder orientation in turbulent environments, following Luk et al. (2005)'s argument that different institutional settings should be examined for stakeholder management differences. These potential indicators have not been evident so far, and are still likely to be found.

\section{REFERENCES}

Adams, M., \& Hardwick, P. (1998). An analysis of corporate donations: United Kingdom evidence. Journal of Management Studies, 35(5), 641-654.

Alberton, A. (2003). Meio ambiente e desempenho econômico-financeiro: o impacto da ISO 14001 nas empresas brasileiras. Tese de doutorado. Universidade Federal de Santa Catarina, Florianópolis, SC, Brasil.

Almeida, G., Fontes, J. Filho, \& Martins, H. (2000, setembro). Identificando stakeholders para formulação de estratégias organizacionais. Anais do Encontro da Associação Nacional de PósGraduação e Pesquisa em Administração, Florianópolis, SC, Brasil, 24. 
Altman, B. W. (1998). Corporate community relations in the 1990s: a study in transformation. Business and Society, 37(2), 221-227.

Alves, L. (2001). Governança e cidadania empresarial. Revista de Administração de Empresas, 41(4), 78-86.

Andrade, J. (2000). Formação de estratégias sócio-ambientais corporativas: os jogos da Aracruz Celulose-partes interessadas. Revista de Administração Contemporânea, 6(2), 75-97.

Ashley, P., Coutinho, R., \& Tomei, P. (2000, setembro). Responsabilidade social corporativa e cidadania empresarial: uma análise conceitual comparativa. Anais do Encontro da Associação Nacional de Pós-Graduação e Pesquisa em Administração, Florianópolis, SC, Brasil, 24.

Balabanis, G., Philips, H. C., \& Lyall, J. (1998). Corporate social responsibility and economic performance in the top British companies: are they linked? European Business Review, 98(1), $25-44$.

Bentler, P. M., \& Chou, C. (1987). Practical issues in structural modeling. Sociological Methods and Research, 16(1), 78-117.

Berman, S. L., Wicks, A. C., Kotha, S., \& Jones, T. M. (1999). Does stakeholder orientation matter? The relationship between stakeholder management models and firm financial performance. Academy of Management Journal, 42(5), 488-506.

Boeira, S. (2002). Atrás da cortina de fumaça: tabaco, tabagismo e meio ambiente: estratégias da indústria e dilemas da crítica. Itajaí: Editora UNIVALI.

Buchholz, R. A., \& Rosenthal, S. B. (2004). Stakeholder theory and public policy: how governments matter. Journal of Business Ethics, 51(2), 143-153.

Campbell, D., Moore, G., \& Metzger, M. (2002). Corporate philanthropy in the U.K. 1985-2000: some empirical findings. Journal of Business Ethics, 39(1/2), 29-41.

Campos, T. (2003). O impacto das políticas para stakeholders sobre o desempenho organizacional das companhias de capital aberto no Brasil: uma conexão (in) provável. Tese de doutorado. Universidade Federal de Minas Gerais, Belo Horizonte, MG, Brasil.

Clarkson, M. B. E. (1995). A stakeholder framework for analyzing and evaluating corporate social performance. Academy of Management Review, 20(1), 92-117.

Cochran, P. L., \& Wood, R. A. (1984). Corporate social responsibility and financial performance. Academy of Management Journal (pre-1986), 27(1), 42-56.

Coelho, M. Q. (2004, setembro). Indicadores de performance para projetos sociais: a perspectiva dos stakeholders. Anais do Encontro da Associação Nacional de Pós-Graduação e Pesquisa em Administração, Curitiba, PR, Brasil, 28.

Cornell, B., \& Shapiro, A. C. (1987). Corporate stakeholders and corporate finance. Financial Management, 16(1), 5-14.

Coutinho, R., \& Macedo-Soares, T. (2002). Gestão estratégica com responsabilidade social: arcabouço analítico para auxiliar sua implementação em empresas no Brasil. Revista de Administração Contemporânea, 6(3), 75-96.

Cowen, S. S., Ferreri, L. B., \& Parker, L. D. (1987). The impact of corporate characteristic on social responsibility disclosure a typology and frequency-based analysis. Accounting Organization and Society, 12(2), 111-122. 
Demsetz, H., \& Lehn, K. (1985). The structure of corporate ownership: causes and consequences. Journal of Political Economy, 93(6), 1155-1177.

Donaldson, T., \& Preston, L. E. (1995). The stakeholder theory of the corporation: concepts, evidence and implications. Academy of Management Review, 20(1), 65-91.

Economática - Tools for Investment Analysis (n.d.). Base de dados. Retrieved March 06, 2007 de http://manual.economatica.com.br

Freeman, R. E. (1998). A stakeholder theory of the modern corporation. In M. B. E. Clarkson (Ed.). The corporations and its stakeholders: classic and contemporary readings (pp. 125-138). Toronto: University of Toronto Press.

Freeman, R. E. (1999). Divergent stakeholder theory. Academy of Management Review, 24(2), 233236.

Freeman, R. E., \& Reed, D. L. (1983). Stockholders and stakeholders: a new perspective on corporate governance. California Management Review (pre-1986), 25(3), 88-106.

Garay, A. B. S. (2006). A responsabilidade social corporativa RSC como elemento de atração de talentos: percepção dos alunos destaques do curso de administração. Revista Eletrônica de Administração, 12(3), Edição 51. Retrieved March 06, 2007, from http://www.read.ea.ufrgs.br/edicoes/download.php?cod_artigo=504\&cod_edicao=51\&cod_lista _edicao $=51$

Hair, J. F., Anderson, R. E., Tatham, R. L., \& Black, W. C. (1998). Multivariate data analysis (5th ed.). New Jersey: Prentice Hall.

Harrison, J. S., \& Freeman, R. E. (1999). Stakeholders, social responsibility and performance: empirical evidence and theoretical perspectives. Academy of Management Journal, 42(5), 479485 .

Hill, C. W. L., \& Jones, T. M. (1992). Stakeholder-agency theory. Journal of Management Studies, 29(2), 131-154.

Hillman, A. J. \& Keim, G. D. (2001). Shareholder value, stakeholder management, and social issues: what's the bottom line? Strategic Management Journal, 22(2), 125-139.

Jensen, M. C., \& Mechling, W. H. (1976). Theory of the firm: managerial behavior, agency costs, and capital structure. Journal of Financial Economics, 3(4), 305-360.

Jones, T. M. (1995). Instrumental stakeholder theory: a synthesis of ethics and economics. Academy of Management Review, 20(2), 404-437.

Keim, G. D., \& Baysinger, B. (1988). The efficacy of business political activity: competitive considerations in a principal-agent context. Journal of Management, 14(2), 163-180.

Kline, R. (2005). Principles and practice of structural equation modeling (2th ed.). New York: The Guilford Press.

Kreitlon, M., \& Quintella, R. (2001, setembro). Práticas de Accountability ética e social: as estratégias de legitimação de empresas brasileiras nas relações com stakeholders. Anais do Encontro da Associação Nacional de Pós-Graduação e Pesquisa em Administração, Campinas, SP, Brasil, 25 .

Lenway, S. A., \& Rehbein, K. (1991). Leaders, followers, and free riders: an empirical test of variation in corporate political involvement. Academy of Management Journal, 34(4), 893-905. 
Luk, C., Yau, O. H. M., Chow, R. P. M., Tse, A. C. B., \& Sin, L. Y. M. (2005). Stakeholder orientation and business performance: the case of service companies in China. Journal of International Marketing, 13(1), 89-110.

Machado, A. L. C. S., \& Lage, A. C. (2002, setembro). Responsabilidade social: uma abordagem para o desenvolvimento social. O caso da CVRD. Anais do Encontro da Associação Nacional de Pós-Graduação e Pesquisa em Administração, Salvador, BA, Brasil, 26.

Macke J., \& Carrion, R. M. (2006). Planejamento, implementação e avaliação de programas sociais: uma proposta de inovação. Revista Eletrônica de Administração, 12(5), Edição 53. Retrieved March 06, 2007, from http://www.read.ea.ufrgs.br/edicoes/download.php?cod_artigo=531\&cod_edicao=54\&cod_lista _edicao=54 http://www.read.ea.ufrgs.br

Macke J., \& Carrion, R. M. (2006). Planejamento, implementação e avaliação de programas sociais: uma proposta de inovação. Revista Eletrônica de Administração, 12(5), Edição 53. Retrieved March 06, 2007, from

McGahan, A. M., \& Porter, M. E. (1997). How much does industry matter, really? Strategic Management Journal, 18(Special Issue), 15-30.

McGuire, J. B., Sundgren, A., \& Schneeweis, T. (1988). Corporate social responsibility and firm financial performance. Academy of Management Journal, 31(4), 854-872.

Pearce, J. (2001). Organization and management in the embrace of government. Mahwah, New Jersey: LEA.

Porter, M. E. (1980). Competitive strategy. New York: Free Press.

Preston, L. E., \& O’Bannon, D. P. (1997). The corporate social-financial relationship: typology and analysis. Business \& Society, 36(4), 419-429.

Revista Exame. (2000). Guia Exame de boa cidadania corporativa (728a ed.). São Paulo: Editora Abril.

Revista Exame. (2001). Guia Exame de boa cidadania corporativa (754a ed.). São Paulo: Editora Abril

Revista Exame. (2002). Guia Exame de boa cidadania corporativa (781a ed.). São Paulo: Editora Abril.

Roberts, R. (1992). Determinants of corporate social responsibility disclosure: an application of stakeholder theory. Accounting Organizations and Society, 17(6), 595-612.

Ruf, B. M., Muralidhar, K., Brown, R. M., Janney, J. J., \& Paul, K. (2001). An empirical investigation of the relationship between change in corporate social performance and financial performance: a stakeholder theory perspective. Journal of Business Ethics, 32(2), 143-156.

Samuels, D. (2003). Financiamento de campanha e eleições no Brasil. In M. Benevides, P. Vannuchi, \& F. Kerche (Orgs.). Reforma política e cidadania. São Paulo: Fundação Perseu Abramo.

Schommer, P. (2000). Investimento social das empresas: cooperação organizacional num espaço compartilhado. Revista Organizações \& Sociedade, 7(19), 145-160.

Serpa, D. A. F. (2006). Ética responsabilidade social corporativa são realmente importantes? Um estudo com futuros e atuais gestores de empresas. Revista Eletrônica de Administração, 12(6). Edição 54, Retrieved March 06, 2007, from http://www.read.ea.ufrgs.br/edicoes/download.php?cod_artigo=544\&cod_edicao=55\&cod_lista _edicao $=55$ 
Serpa, D. A. F., \& Fourneau, L. F. (2007). Responsabilidade Social Corporativa: uma Investigação sobre a Percepção do Consumidor. Revista de Administração Contemporânea, 11(3), 83-103.

Siffert, M. Filho (1998). Governança corporativa: padrões internacionais e evidências empíricas no Brasil nos anos 90. Revista do BNDES, 5(9), 123-146.

Siqueira, T. (1998). Concentração da propriedade nas empresas brasileiras de capital aberto. Revista do BNDES, 5(10), Retrieved April 02, 2007, from http:// http://www.bndes.gov.br/conhecimento/publicacoes/catalogo/revista.asp

Smith, C. (1994). The new corporate philanthropy. Harvard Business Review, 72(3), 105-116.

Souza, M. J. B., \& Marcon, R. (2003, December). Responsabilidade social corporativa, vantagem competitiva e desempenho financeiro. Proceedings of the Iberoamerican Academy of Management International Conference, São Paulo, SP, Brasil, 3.

Stevens, J. (2001). Applied multivariate statistics for the social science (4th ed.). Mahwah, New Jersey: LEA.

Thomsem, S. \& Pedersen, T. (1997, September). Empirical determinants of corporate ownership structure. Proceeding of the Inaugural Conference of the International Society for New Institutional Economics, St. Louis, Missouri, 1.

Ullmann, A. A. (1985). Data in search of a theory: a critical examination of the relationships among social disclosure, and economic performance of U.S. firms. Academy of Management Review (pre-1986), 10(3), 540-557.

Vergara, S., \& Branco, P. (2001). Empresa humanizada: a organização necessária e possível. Revista de Administração de Empresas, 41(2), 20-30.

Vieira, S., \& Mendes, A. (2004). Governança corporativa: uma análise de sua evolução e impactos no mercado de capitais brasileiro. Revista do BNDES, 11(22), 103-122.

Waddock, S. A., \& Graves, S. B. (1997). The corporate social performance-financial performance link. Strategic Management Journal, 18(4), 303-319.

Williamson, O., \& Winter, S. (Eds.). (1991). The nature of the firm: origins, evolution and development. New York: Oxford University Press.

Xavier, A., \& Souza, W. (2004, setembro). Responsabilidade social empresarial: estudo teóricoempírico à luz dos instrumentos Ethos. Anais do Encontro Nacional da Associação Nacional de Pós-Graduação e Pesquisa em Administração, Curitiba, PR, Brasil, 28. 